\title{
GROUND-WATER FLOW IN THE DUCHESNE RIVER-UINTA AQUIFER, UINTA BASIN, UTAH AND COLORADO
}

By Kent C. Glover

\section{U.S. GEOLOGICAL SURVEY}

Water-Resources Investigations Report 92-4161 


\section{U.S. DEPARTMENT OF THE INTERIOR BRUCE BABBITT, Secretary}

\section{U.S. GEOLOGICAL SURVEY}

Gordon P. Eaton, Director

The use of trade, product, industry, or firm names is for descriptive purposes only and does not imply endorsement by the U.S. Government.

For additional information write to:

\section{District Chief}

U.S. Geological Survey, WRD

2617 E. Lincolnway, Suite B

Cheyenne, Wyoming 82001-5662
Copies of this report can be purchased from:

U.S. Geological Survey

Branch of Information Services

Box 25286, Denver Federal Center

Denver, Colorado 80225 


\section{CONTENTS}

Abstract
Introduction .
Duchesne River-Uinta aquifer and associated geohydrologic units
Distribution of hydraulic head in the Duchesne River-Uinta aquifer
Recharge and discharge in the Duchesne River-Uinta aquifer
Aquifer properties
Analysis of steady-state flow in the Duchesne River-Uinta aquifer
Development of flow model
Initial estimates of hydraulic characteristics
Calibration
Recharge
Discharge
Transmissivity

\section{FIGURES}

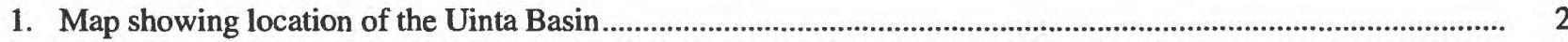

2. Stratigraphic relation between early Oligocene and Eocene geologic units and geohydrologic units .................. 4

3-5. Maps showing:

3. Altitude and configuration of the base of the Uinta Formation ......................................................................

4. Surficial geology of the Uinta Basin and adjacent areas................................................................................. 6

5. Potentiometric surface (1985) of the Duchesne River-Uinta aquifer ........................................................... 7

6. Graph showing variograms of hydraulic head in the Duchesne River-Uinta aquifer ........................................... 8

7. Map showing initial distribution of estimated ground-water recharge ................................................................ 11

8. Graph showing variogram of hydraulic conductivity for the Duchesne River-Uinta aquifer............................... 13

9-13. Maps showing:

9. Finite-difference grid used to model ground-water flow in the Duchesne River-Uinta aquifer ................... 14

10. Model-calibrated recharge for the Duchesne River-Uinta aquifer.......................................................... 17

11. Basin distribution of transmissivity for the Duchesne River-Uinta aquifer .............................................. 19

12. Simulated hydraulic-head contours for the Duchesne River-Uinta aquifer .............................................. 21

13. Residuals for the Duchesne River-Uinta aquifer model ...................................................................... 22

\section{TABLES}

1. Ground-water discharge from the Duchesne River-Uinta aquifer to streams in the Uinta Basin estimated from streamflow data

2. Ground-water recharge and discharge along the Green and Uinta Rivers estimated during model development 


\section{CONVERSION FACTORS AND VERTICAL DATUM}

\begin{tabular}{rll}
\hline Multiply & By & To obtain \\
\hline inch (in.) & & millimeter \\
foot (ft) & 25.4 & meter \\
mile (mi) & 0.3048 & kilometer \\
square mile ( $\left.\mathrm{mi}^{2}\right)$ & 1.609 & square kilometer \\
cubic foot per second $\left(\mathrm{ft}^{3} / \mathrm{s}\right)$ & 2.590 & cubic meter per second \\
& 0.02832 & \\
\hline
\end{tabular}

Sea level: In this report "sea level" refers to the National Geodetic Vertical Datum of 1929 (NGVD of 1929)--a geodetic datum derived from a general adjustment of the first-order level nets of both the United States and Canada, formerly called Sea Level Datum of 1929. 


\title{
GROUND-WATER FLOW IN THE DUCHESNE RIVER-UINTA AQUIFER, UINTA BASIN, UTAH AND COLORADO
}

\author{
By Kent C. Glover
}

\section{ABSTRACT}

The Duchesne River and Uinta Formations form the Duchesne River-Uinta aquifer, an important basin aquifer that is about 8,000 feet thick in the north-central part of the Uinta Basin in Utah and Colorado. Ground-water recharge within the Duchesne River-Uinta aquifer is derived from precipitation and from seepage losses from canals and streams, while ground-water discharge is to perennial streams. Hydraulic conductivity of the Duchesne River-Uinta aquifer is related to lithology and the degree of fracturing.

Ground water in the Duchesne River-Uinta aquifer exists within both local and basin flow systems. The difference in hydraulic head expressed by measurements less than 5 miles apart is caused by local hydrologic effects. The difference in hydraulic head expressed by measurements separated by 5 to 40 miles is caused by both local and basin effects. The difference in hydraulic head expressed by measurements greater than 40 miles apart is caused by basin effects.

Basin geohydrologic characteristics of the Duchesne River-Uinta aquifer are described by a steady-state flow model that simulates about 4,190 square miles of area with regular node spacing of 2.5 miles. Simulated recharge from precipitation is 262 cubic feet per second. Recharge in the southern part of the model area is less than previously calculated while recharge in areas adjacent to the Uinta Mountains is greater. Simulated ground-water recharge from the Green River is about 8 cubic feet per second; ground-water discharge to the Uinta River is about 45 cubic feet per second. Simulated ground-water discharge to other streams is not substantially different from initial estimates. The total discharge from the Duchesne River-Uinta aquifer to streams of the Uinta Basin is about 270 cubic feet per second.
Large areas of the Duchesne River-Uinta aquifer are characterized by a transmissivity of about 4,400 feet squared per day. In the center of the model area, an aquifer test indicated a value of 900 feet squared per day where the model yielded a value of 4,400 feet squared per day with an estimated standard error of 1,500 feet squared per day. Transmissivity within the Duchesne fault zone in the western part of the study area and along the Uinta Mountains is less.

Simulated hydraulic head compared well with measured hydraulic head as described by a coefficient of variation of 0.97 . The root-meansquared residual was $187 \mathrm{feet}$, smaller than the 202 feet criterion determined by variogram analyses. This difference between calculated and measured water levels shows that basin variations in transmissivity, recharge, and discharge are adequately described.

\section{INTRODUCTION}

The Duchesne River-Uinta aquifer is an important source of ground water for irrigation, domestic, and industrial use within the Uinta Basin of Utah and Colorado (fig. 1). The Duchesne River-Uinta aquifer includes both the Duchesne River Formation of late Eocene and early Oligocene age and the Uinta Formation of late Eocene age, because these two formations act as a single geohydrologic unit and interfinger at the east and west ends of the basin (Hood, 1976; L.J. Martin, U.S. Geological Survey, written commun., 1986). Ground water in the aquifer exists under a complex system of shallow water-table, perched, and deep artesian conditions.

Hydrologic studies previously have been done on parts of the Duchesne River-Uinta aquifer (Price and Miller, 1975; Hood, 1976; and Hood and Fields, 1978), but the lateral boundaries of these studies did not coincide with the lateral boundaries of the aquifer. Internal boundaries of the aquifer, such as the Duch- 


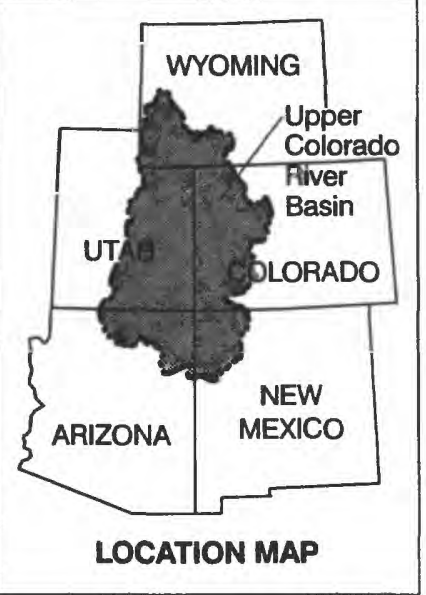

EXPLANATION

AREA EXCLUDED FROM

REGIONAL AQUIFER

SYSTEM ANALYSIS

BOUNDARY OF THE UPPER

COLORADO RIVER BASIN

BOUNDARY OF THE UINTA BASIN

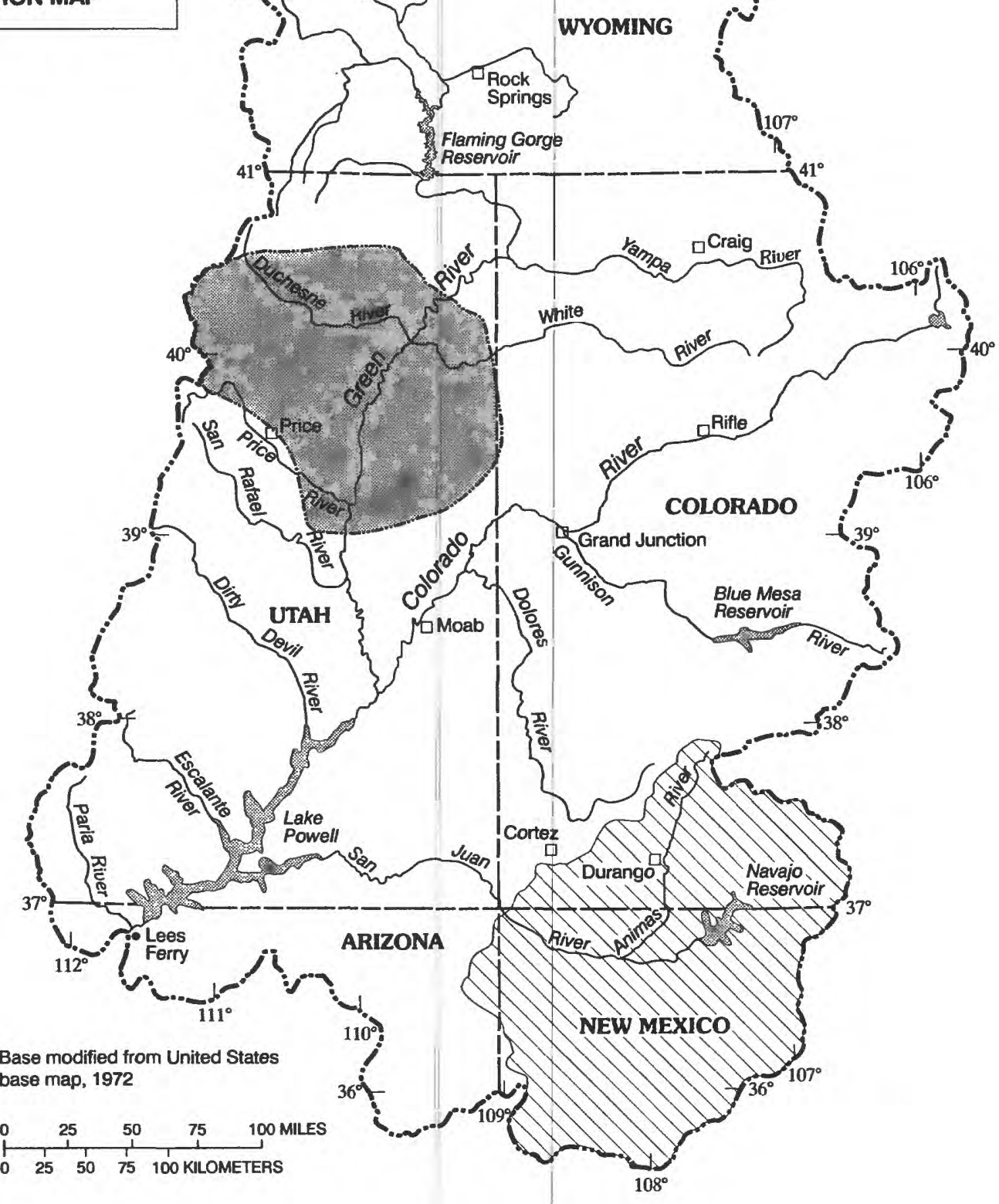

Figure 1. Location of the Uinta Basin. 
esne River, typically have been used as external study boundaries. As a result, the earlier investigators have been unable to estimate components of the hydrologic budget independently and compare the estimates for consistency. Comparisons of changes in estimated aquifer properties with the estimated hydrologic budget also have not been possible. Such comparisons are an important step in understanding the ground-water flow system in the Duchesne River-Uinta aquifer.

The purpose of this report is to develop and present estimates of aquifer properties and components of the hydrologic budget of the Duchesne River-Uinta aquifer. Independent estimates of transmissivity, aquifer recharge, and aquifer discharge are made using existing interpretations or hydrologic data. Estimates are compared and, where needed, revised using a digital model of ground-water flow. The study was a part of the Upper Colorado Regional Aquifer System Analysis (RASA) program of the U.S. Geological Survey. The purpose of the Upper Colorado RASA is to provide regional assessments of major aquifer systems for which data are available (Taylor and others, 1983).

\section{DUCHESNE RIVER-UINTA AQUIFER AND ASSOCIATED GEOHYDROLOGIC UNITS}

About $8,000 \mathrm{ft}$ of rocks make up the Duchesne River-Uinta aquifer and are part of the thick sequence of sedimentary rocks within the Uinta Basin. As much as $15,000 \mathrm{ft}$ of Tertiary and younger rocks have been penetrated in the basin while drilling for oil and gas.

The geohydrologic units considered in this study in descending order are, the Duchesne River-Uinta aquifer, the Parachute Creek confining unit, the Douglas Creek-Renegade aquifer, and the Wasatch-Green River confining unit (fig. 2). Alluvial and glacial deposits have not been mapped because of their generally limited nature at the scale of the final mapping. However, a narrow strip (generally less than $1 \mathrm{mi}$ wide) of alluvium occurs along perennial streams such as the Green, Duchesne, Lake Fork, Strawberry, and White Rivers, and Red Creek. Thickness of the alluvium generally is less than $50 \mathrm{ft}$.

The Duchesne River-Uinta aquifer consists of rocks from the Duchesne River Formation and the Uinta Formation. The combined thickness of the formations where they both are present is about $8,000 \mathrm{ft}$.

The Duchesne River Formation overlies the Uinta Formation (fig. 2) and consists dominantly of variegated red shale, siltstone, sandstone, and conglomerate. The Duchesne River Formation is about $3,000 \mathrm{ft}$ thick in the center of the basin (Hintze, 1988,
Hood, 1976). It is composed of coarse-grained rocks where it thins near basin margins. The formation is slightly to highly fractured in most areas. Well yields typically are about 30 to $40 \mathrm{gal} / \mathrm{min}$ and range from less than 1 to about $300 \mathrm{gal} / \mathrm{min}$. Well yields are largest where the formation is fractured.

The Uinta Formation overlies the Green River Formation (fig. 2) and consists of thinly bedded calcareous shale, siltstone, and fine-grained sandstone. The Uinta Formation is as much as $5,000 \mathrm{ft}$ thick in the center of the basin but thins toward the margins of the basin (Hintze, 1988; Andersen and Picard, 1972). The altitude and configuration of the base of the Uinta Formation are shown in figure 3 . Hydraulic conductivity of the formation is greatly enhanced by fracturing. The formation yields water to wells except in the southern part of the basin where deeply incised streams have drained the formation.

Water in the Duchesne River-Uinta aquifer generally is under artesian conditions in the central part of the basin, probably due to variable surficial geology and attendant variable vertical hydraulic conductivity. Water-table conditions exist where the Duchesne River-Uinta aquifer is only partially saturated or eroded in upland areas. One possible explanation for the variable surficial geology and hydraulic conductivity is precipitation of minerals from the ground water such that fractures near land surface have been effectively sealed. The presence of relatively impermeable gilsonite veins near Roosevelt, Utah, provides some support for this explanation (Hood and Fields, 1978, p. 36).

The Parachute Creek confining unit, consisting of the Parachute Creek and Garden Gulch Members of the Green River Formation of Eocene age, underlies the Duchesne River-Uinta aquifer and overlies the Douglas Creek-Renegade aquifer. Although localscale ground-water flow occurs within the Parachute Creek (Kimball, 1981; and Holmes and Kimball, 1983), it is assumed to be a basin confining unit. This assumption is credible because there is no evidence of vertical flow between the Douglas Creek-Renegade aquifer and the Duchesne River-Uinta aquifer. Also, Holmes and Kimball (1983) were able to successfully model ground-water flow in the Douglas Creek-Renegade aquifer without consideration of vertical groundwater flow.

The Douglas Creek-Renegade aquifer, consisting of the Douglas Creek Member of the Green River Formation and the Renegade Tongue of the Wasatch Formation is a basin aquifer underlying the Duchesne River-Uinta aquifer. The stratigraphic relation of these two aquifers and associated confining units is shown in 


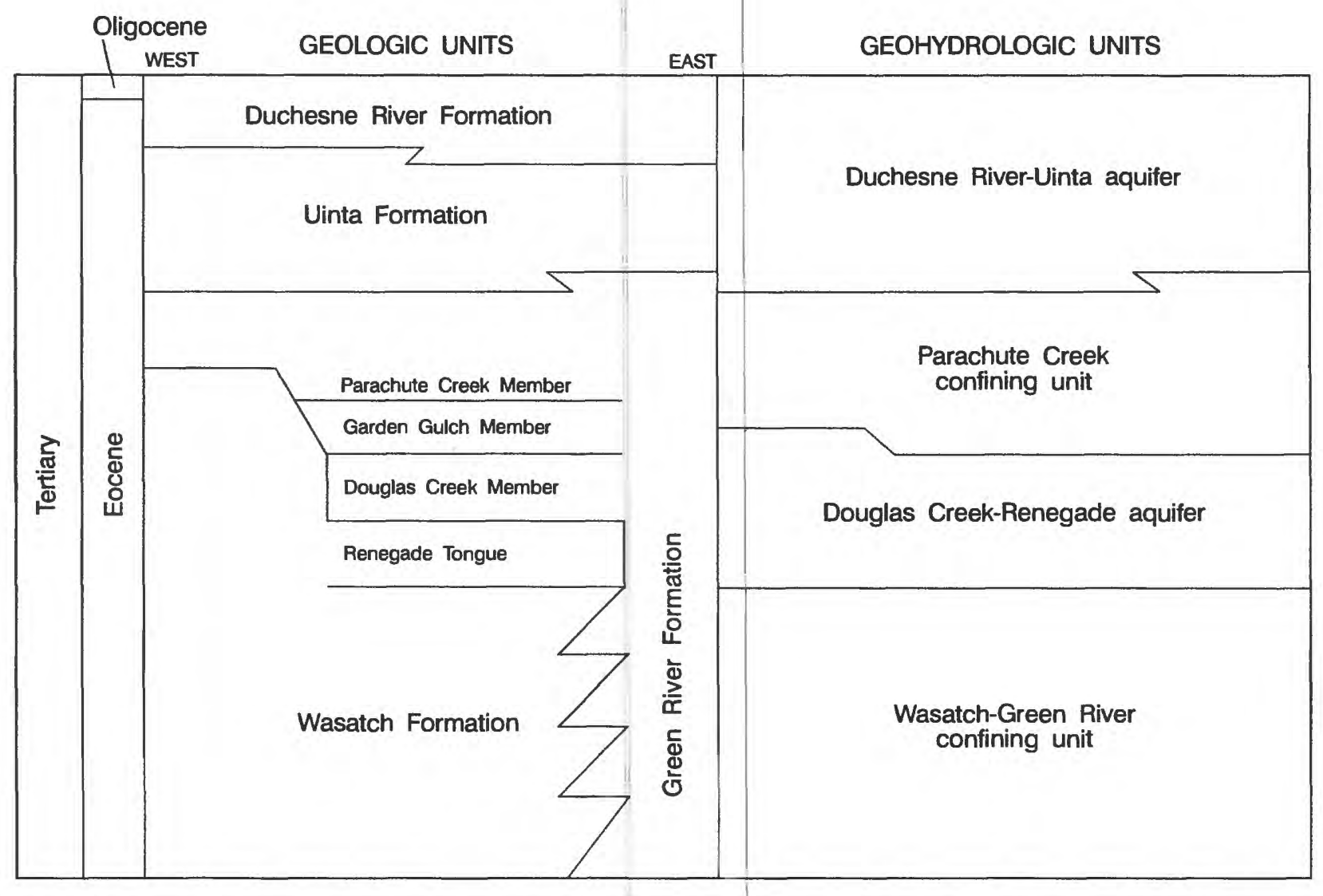

Figure 2. Stratigraphic relation between early Oligocene and Eocene geologic units and geohydrologic units.

figure 2; the surficial geology of the Uinta Basin is shown in figure 4. The Douglas Creek-Renegade aquifer is the thicker of the two aquifers and has a hydraulic conductivity ranging from 0.05 to $0.25 \mathrm{ft} / \mathrm{d}$ in the southeastern part of the Uinta Basin (Holmes and Kimball, 1983). In the northern and western parts of the Uinta Basin the aquifer becomes predominantly shale.

The Wasatch-Green River confining unit, composed of the Wasatch Formation below the Renegade Tongue and the Green River Formation below the Douglas Creek Member, underlies the Douglas CreekRenegade aquifer (fig. 2) and overlies unfractured limestone of the Paleocene and Upper Cretaceous North Horn Formation. In the eastern part of the Uinta Basin, the North Horn is absent, and the WasatchGreen River confining unit overlies the Mesaverde Group.

\section{DISTRIBUTION OF HYDRAULIC HEAD IN THE DUCHESNE RIVER-UINTA AQUIFER}

The potentiometric surface of the Duchesne River-Uinta aquifer (fig. 5) shows basin variations in hydraulic head and can be used to infer the direction of basin ground-water movement. Ground water generally moves in directions perpendicular to potentiometric contours. In fractured rocks such as the Duchesne River-Uinta aquifer, directions of movement may not be perpendicular to contour lines. The actual direction of flow is controlled by both the hydraulic gradient, as indicated on the potentiometric-surface map, and the preferred direction of hydraulic conductivity. Water in the Duchesne River-Uinta aquifer moves from upland areas adjacent to the Uinta Mountains and along the southern margins of the basin, towards the major streams of the Uinta Basin. 


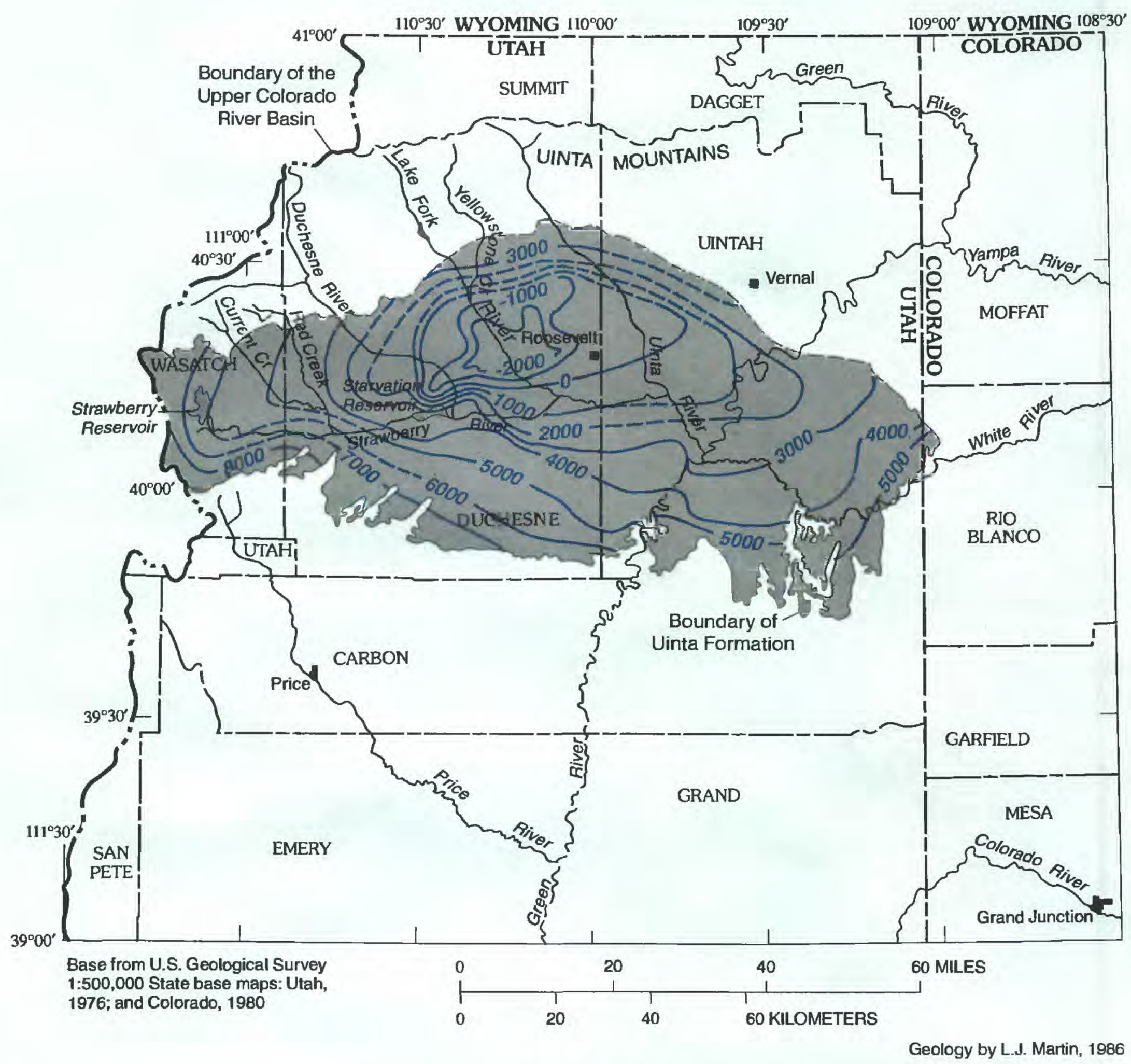

\section{EXPLANATION}

- 7000 -- STRUCTURE CONTOUR SHOWING ALTITUDE OF BASE OF UINTA FORMATION--Dashed where approximately located. Contour interval is 1,000 feet. Datum is sea level

Figure 3. Altitude and configuration of the base of the Uinta Formation. 


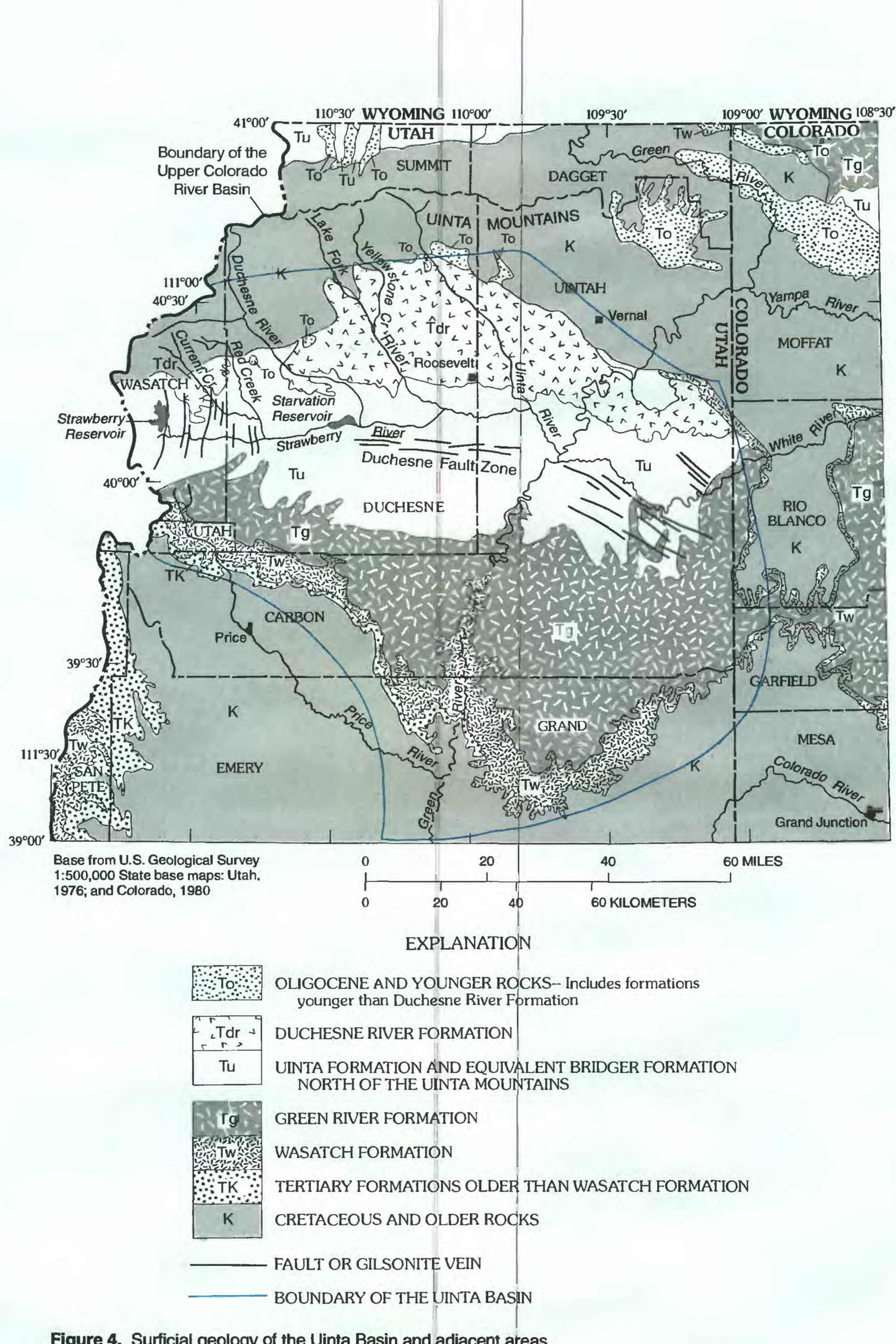




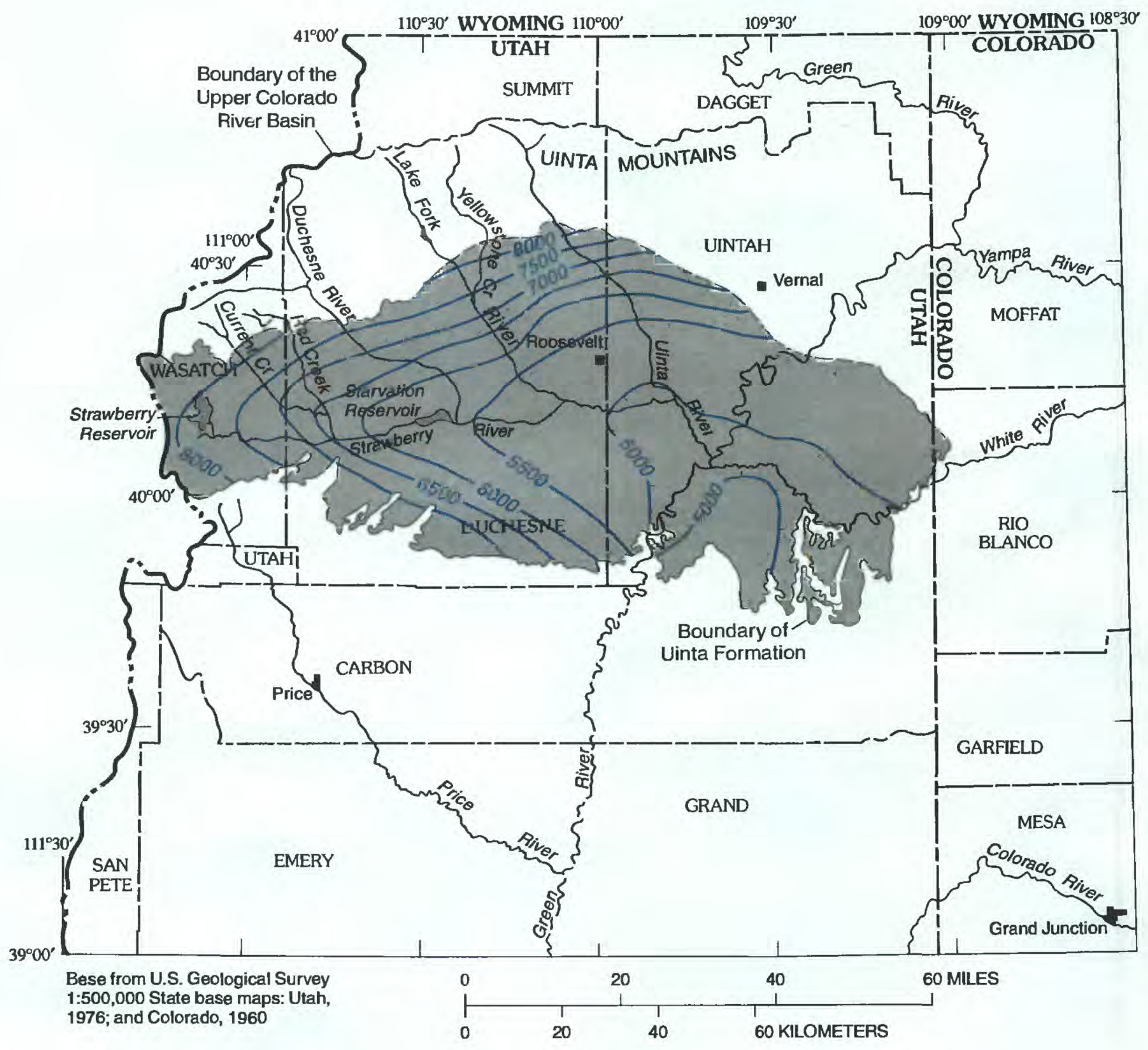

Hydrology by K.C. Glover, 1986

EXPLANATION

- 6500 - POTENTIOMETRIC CONTOUR-Shows altitude at which water level would have stood in tightly cased wells, 1985. Contour interval is 500 feet. Datum is sea level

Figure 5. Potentiometric surface (1985) of the Duchesne River-Uinta aquifer. 
The potentiometric surface of the Duchesne River-Uinta aquifer (fig. 5) is believed to represent steady-state conditions at the scale of this study, even though the aquifer has been developed as a water supply in the northern half of the basin. Although the total quantity of water withdrawn from the aquifer is not large, prolonged pumping has caused declines in the potentiometric surface as large as $100 \mathrm{ft}$ (Hood and Fields, 1978, p. 34). Given the accuracy of the potentiometric-surface map implied by the contour interval, water levels measured in wells near pumped or flowing wells are not substantially different from steady-state conditions. Water-level data obtained from pumping or flowing wells were not used in constructing the map.

Although the analysis that resulted in the potentiometric-surface map was designed to construct a map showing basin variations in hydraulic head, a separate part of the analysis involved the consideration of the extent to which local variations in flow were present in the aquifer. Examples of local variations in flow include ground-water discharge to springs in upland areas that are areas of recharge to the basin flow system, and vertical leakage from overlying terrace deposits between incised streams that receive discharge from the basin flow system. Such a consideration was necessary because local variations in flow in the Duchesne River-Uinta aquifer are common, and the accuracy of basin analyses of hydraulic heads decreases as the magnitude of local variations in head increases.

The relation between the local and basin groundwater flow systems was analyzed using variograms of hydraulic head. Variograms are powerful tools for analyzing data and form the basis of kriging, a technique used for data interpolation. A detailed discussion of the method used to construct the variograms of hydraulic head in the Duchesne River-Uinta aquifer (fig. 6) is beyond the scope of this report. For the interested reader, the method is described in detail by Journel and Huijbregts (1978) and Skrivan and Karlinger (1980). To aid readers unfamiliar with the subject, a brief discussion of terms used in variogram analysis will be given.

A variogram is a plot of the variance (one-half the mean-squared difference) of paired sample measurements as a function of the distance between samples. The variograms presented in this report are obtained directly from the basic data and are considered empirical. In applications such as kriging, a theoretical mathematical model is fit to the empirical variogram to obtain a smooth function that is readily used in further analysis. No models are used to describe variograms in this report. If there is reason to expect a basin trend in the data, an empirical variogram can be calculated that includes the effects of the trend

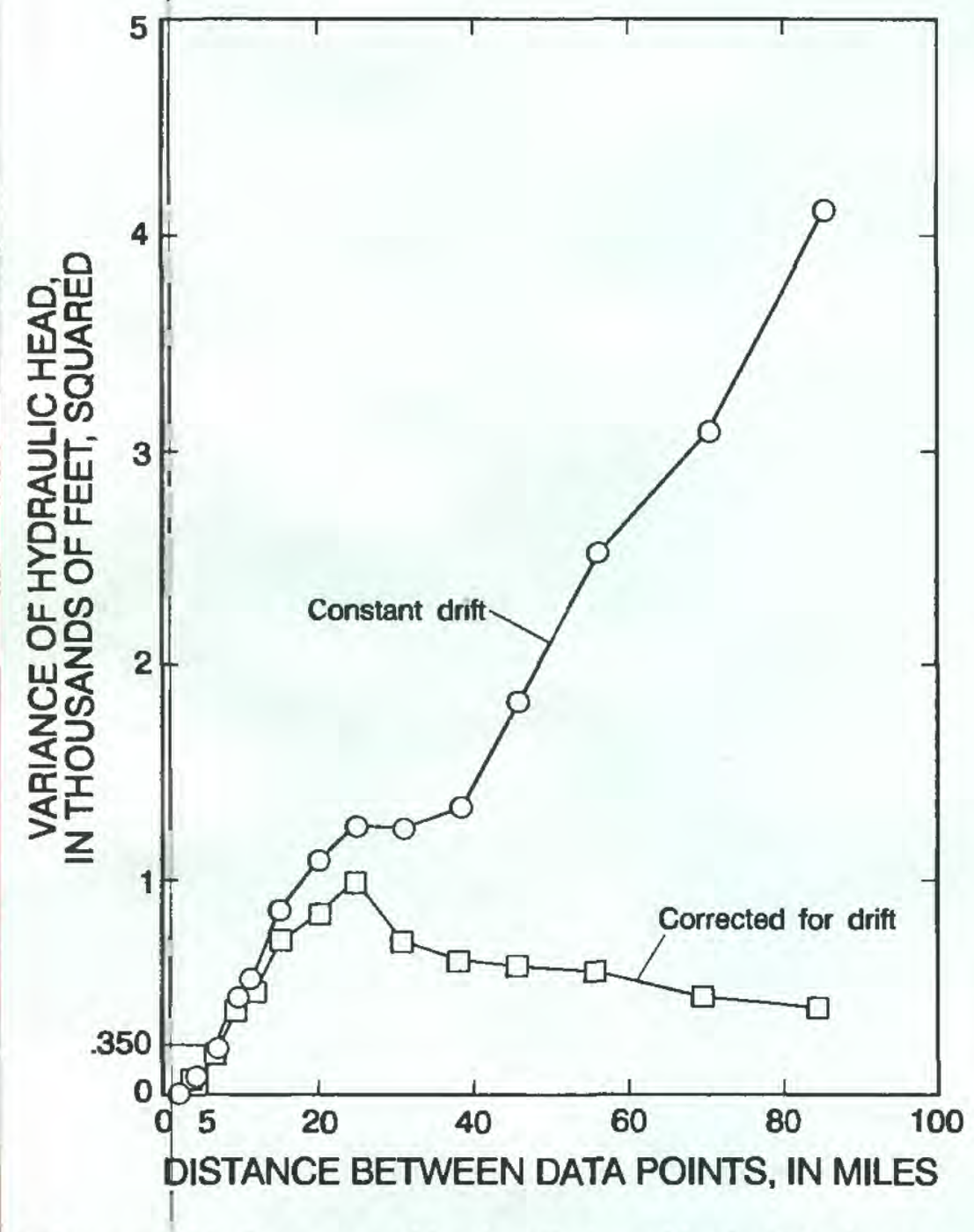

Figure 6. Variograms of hydraulic head in the Duchesne River-Uinta aquifer.

(variogram with constant drift), or a variogram can be calculated that removes the effects of the trend (variogram corrected for drift). Both types of variograms are used in this report.

Many important inferences can be made from an empirical variogram. The distance beyond which there is little or no correlation among data will show as points where the variance plots as an approximately horizontal line on the variogram; no change in variance with additional distance between points. A qualitative measure of regularity of continuity of data is given by the degree to which the empirical variogram plots as a smooth curve. Empirical variograms in this report are used to evaluate the relative importance of basin trends and local variations from trends that are simply a function of distance. This information is used to establish reasonable nodal spacing and calibration criteria for digital modeling of ground-water flow.

Two variograms were developed in the analysis of hydraulic head in the Duchesne River-Uinta aquifer (fig. 6). The first is a variogram with constant drift; the second is a variogram corrected for drift. The variograms are used to determine expected variation in 
water levels in the Duchesne River-Uinta aquifer between two sites. For example, in the Duchesne River-Uinta aquifer, water levels in wells $20 \mathrm{mi}$ apart typically vary by $1,040 \mathrm{ft}$. The value of $1,040 \mathrm{ft}$ was obtained from the variogram with constant drift by taking the square root of the variance in hydraulic head associated with wells $20 \mathrm{mi}$ apart.

The principal reason for developing two curves is that both curves are needed to determine if a difference in hydraulic head between two measurement points is an indication of basin trends or local variations. The variation in head between measurement points as determined from the variogram with constant drift includes variations due to both local and basin effects on the flow system. The variation determined from the curve corrected for drift is due only to local effects. The difference between the two curves is the variation in head due to basin trends or effects.

The following assumptions were made on the basis of comparison of the two curves:

1. The difference in hydraulic head expressed by measurements or data points less than about $5 \mathrm{mi}$ apart is caused by local hydrologic effects. At this distance, there is virtually no difference between the two curves, and therefore, there are no basin effects.

2. The difference in hydraulic head expressed by measurements or data points separated by about 5 to 40 mi is caused by both local and basin effects. However, the greater the distance between data points the more likely that differences in head values are caused by basin effects. This transition from dominantly local to basin effects corresponds with the definition of intermediate-flow systems of Toth (1963).

3. The difference in hydraulic head expressed by measurements or data points greater than about $40 \mathrm{mi}$ apart is caused by basin effects.

The variogram corrected for drift also can be used to estimate the possible accuracy in a model analysis of ground-water levels in the Duchesne RiverUinta aquifer. Such a model analysis is discussed in later sections of this report. Because basin flow modeling does not incorporate hydrologic processes that occur at a local scale, the model cannot be expected to simulate hydraulic heads with greater accuracy than that given by the statistical description of the drift. Basin trends in hydraulic head cannot be detected at a scale less than $5 \mathrm{mi}$. At a scale of $5 \mathrm{mi}$, the head variance corrected for drift is about $129,000 \mathrm{ft}^{2}$. This means that after statistically accounting for basin trends in hydraulic-head data, a variance of about $129,000 \mathrm{ft}^{2}$ remains unexplained. The variance represents an appropriate calibration criterion for development of a basin flow model. The average difference in head for points separated by $5 \mathrm{mi}$, obtained as the square root of the variance (about $129,000 \mathrm{ft}^{2}$ ) is $359 \mathrm{ft}$. When simulated hydraulic head compares to measured heads with an average error of approximately $359 \mathrm{ft}$, the model can be considered to be a reasonable representation of the basin flow system.

\section{RECHARGE AND DISCHARGE IN THE DUCHESNE RIVER-UINTA AQUIFER}

Ground-water recharge to the Duchesne RiverUinta aquifer is derived from precipitation and from seepage from canals and streams, and percolation losses from irrigated lands (Price and Miller, 1975; and Hood and Fields, 1978). However, the recharge is assumed to occur only in areas where water-table conditions exist. In areas where artesian conditions exist, the aquifer is overlain by sedimentary materials having smaller hydraulic conductivities that impede recharge. The principal source of ground-water recharge is precipitation on outcrops at high altitudes along the rim of the basin. A percentage of the rainfall and melting snow percolates directly into the underlying sedimentary rocks as does water from streams and canals.

Price and Miller (1975) and Hood and Fields (1978) estimated ground-water recharge in the Uinta Basin using a method that assumed recharge is a percentage of average annual precipitation. The method takes into account geology and physiography as well as the volume, time, and areal distribution of precipitation. The method accounts for not only the amount of recharge resulting from direct percolation of precipitation but also for recharge from unlined canals and streams. Ground-water recharge from percolation losses from irrigated lands were combined with irrigation return flow by Hood and Fields (1978).

Price and Miller (1975) and Hood and Fields (1978) assumed that as average annual precipitation increases, so does the percent of average annual precipitation that recharges the ground water. For example, they assumed if annual precipitation is 10 to 12 in., ground-water recharge is 1 percent of the precipitation; 
if annual precipitation is 16 to $18 \mathrm{in}$., ground-water recharge is 5 percent of the precipitation. The percentage increases to 25 percent for precipitation in excess of 26 in. Precipitation data compiled by Fields and Adams (1975) were used in the calculation process.

The estimates of ground-water recharge to the Duchesne River-Uinta aquifer are shown in figure 7 and were the initial values used in the ground-water flow model developed as part of this study. During the process of model development these initial recharge estimates were modified.

The potentiometric surface for the Duchesne River-Uinta aquifer (fig. 5) indicates that the aquifer discharges to perennial streams in the basin, except for parts of Lake Fork River. Actually, discharge is from the Duchesne River-Uinta aquifer into the thin alluvial deposits along the major streams where water is lost by evapotranspiration and seepage into stream channels. Most springs in the Uinta Basin are in upland areas, discharge at relatively slow rates, and probably are part of local rather than basin flow systems. Spring discharge in lowland areas occurs along streams and in this report is assumed part of seepage into stream channels.

Accurate direct measurement of discharge from the Duchesne River-Uinta aquifer is not possible. Estimates of water lost as evapotranspiration by phreatophytes (Hood and Fields, 1978) must be made on the basis of (1) depths to water, (2) vegetation types and density, and (3) rates of water use that consider the rate of precipitation, the availability of irrigation water, and the plant type. Estimates of discharge by seepage into stream channels have been made (Price and Miller, 1975; and Hood and Fields, 1978) based on the difference between estimated recharge and evapotranspiration and other independently estimated forms of discharge. In general, seepage to streams is estimated to be approximately one-half of total discharge. It is apparent that existing discharge estimates are dependent on recharge estimates; errors made in estimating recharge will propagate into discharge estimates.

Gains or losses in average January streamflow for paired streamflow stations on several perennial streams were compared in an attempt to estimate ground-water discharge in the Uinta Basin (table 1). The assumption was made that ground-water discharge to streams can be better estimated using January streamflow than other months. During January the effects of evapotranspiration, bank storage in alluvium,
Table 1. Ground-water discharge from the Duchesne River-Uinta aquifer to streams in the Uinta Basin estimated from streamflow data

\begin{tabular}{|lc}
\hline \multicolumn{1}{|c|}{ Stream } & $\begin{array}{c}\text { Ground-water } \\
\text { discharge } \\
\text { (cubic feet per } \\
\text { second) }\end{array}$ \\
\hline $\begin{array}{c}\text { Duchesne River-Contact with rocks of } \\
\text { Cretacepus age to Strawberry River } \\
\text { Strawberry River-Strawberry Reservoir } \\
\text { to Red Creek }\end{array}$ & 30 \\
$\begin{array}{l}\text { Currant Cifeek and Red Creek } \\
\text { Strawberry River-Red Creek to } \\
\text { Starvation Reservoir }\end{array}$ & 15 \\
$\begin{array}{l}\text { Duchesne River-Strawberry River to } \\
\text { Lake Fork River }\end{array}$ & 10 \\
$\begin{array}{l}\text { Lake Fork River } \\
\text { Duchesne } \\
\text { Uinta River-Lake Fork River to }\end{array}$ & 76 \\
White River & 23 \\
Total & 54 \\
\hline & 11 \\
\hline
\end{tabular}

surface runoff from ungaged drainages (drainage areas without streamflow-gaging stations) and diversions were assumed to be at a minimum. However, January streamflow records typically also include record gaps due to ice conditions. Such gaps must be filled in by estimates. Therefore, January measurements may not be as accurate as records for other months. In addition, numerous small ungaged drainages may contribute water between paired gaging stations. The streamflow of these ungaged drainages was neglected in the analysis of gains or losses. Therefore, the estimates in table 1 are considered to be initial streamflow gain approximations to be used as initial model input. The figures were revised during flow-model calibration.

The attempt to quantify ground-water discharge to the Green and Uinta Rivers using streamflow records for paired gaging stations on the two rivers was not successful. Differences in streamflow between paired gaging stations were within the accuracy of measurements. Attempts to calculate streamflow loss or gain on the basis of changes in chemical load also were unsuccessful.

It may be coincidental that total estimated recharge $\left(202 \mathrm{ft}^{3} / \mathrm{s}\right)$ is within $24 \mathrm{ft}^{3} / \mathrm{s}$ of total estimated discharge, or it may indicate that the estimates are reasonable. In a steady-state system the two estimates are 


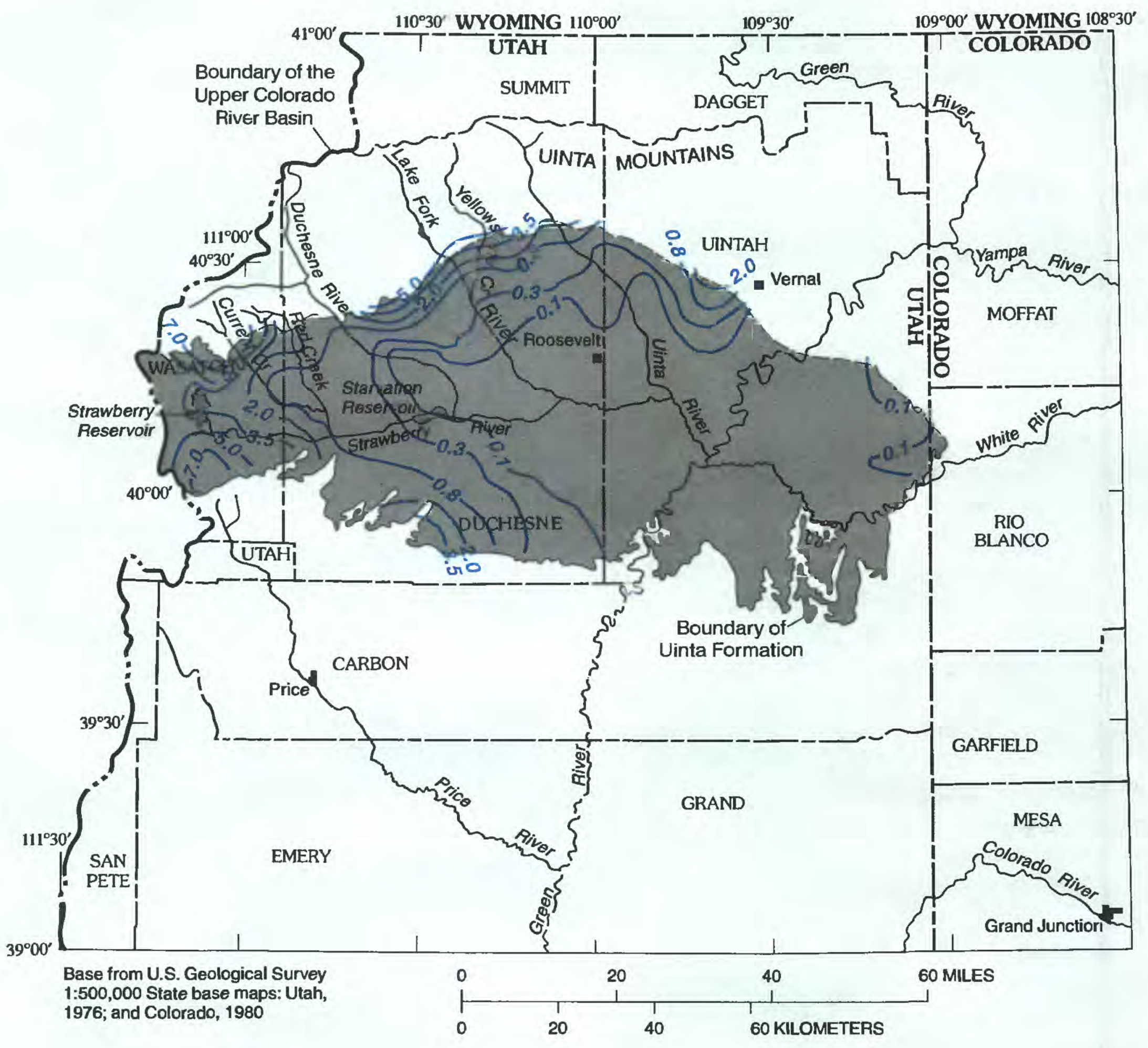

EXPLANATION

- 0.8 - LINE OF EQUAL ESTIMATED GROUND WATER RECHARGE-Interval, in inches per year, varies

Figure 7. Initial distribution of estimated ground-water recharge. 
equal by definition. The small difference between these independent estimates of recharge and discharge could be accounted for as recharge along the Green and Uinta Rivers.

\section{AQUIFER PROPERTIES}

Flow in the Duchesne River-Uinta aquifer is primarily through a network of fractures; however, flow rates between fractures and pores of the rock matrix are probably very slow. Flow through fracture networks can be described within the framework of an equivalent porous media if an equivalent hydraulic-conductivity tensor exists that can predict the correct ground-water flux regardless of the direction of the hydraulic gradient (Long and others, 1982). This description of flow through fracture networks implies that the value of hydraulic conductivity is virtually unchanged with the addition or subtraction of a few fractures to the volume of rock considered. Flow through fracture networks can be described using concepts such as hydraulic conductivity at large scales, generally much larger than the average length of fractures. However, determination of the scale at which concepts of flow through porous media may be used requires detailed knowledge of the distributions of fracture lengths, orientations, apertures, locations, and interconnections. Such information is not available for the Duchesne River-Uinta aquifer.

At scales considered in basin-flow analysis, where distance between digital-model nodes is measured in miles, flow through the fracture network of the Duchesne River-Uinta aquifer probably can be considered within a framework of porous-media flow. The fact that basin aquifer properties can be described by concepts such as hydraulic conductivity or storage coefficient does not automatically imply that flow to a well at a local scale can be evaluated using the same concepts. It also does not imply that estimates of hydraulic conductivity or storage coefficient made at a local scale during aquifer tests can be used at basin scale. Estimates made without the benefit of data from observation wells are particularly unreliable.

The relation between flow in fracture networks and through equivalent porous media should be considered in studies of the Duchesne River-Uinta aquifer. Hood (1976) showed that the distribution of hydraulic conductivity in the aquifer, as indicated by core tests, is similar to the distribution of sandstone porosity. The hydraulic conductivity of cores was small, generally less than $1.5 \mathrm{ft} / \mathrm{d}$. Hydraulic conductivity, measured by specific-capacity tests, generally was substantially larger than that measured by core tests. Hood concluded that the larger values were the result of fractures. Hood also noted that larger well yields generally were associated with areas known to be fractured.

A single aquifer test with observation wells has been reported for the Duchesne River-Uinta aquifer (Hood, 1976). Test data were interpreted, within a framework of homogeneous porous media, using image-well theory. A value of $900 \mathrm{ft}^{2} / \mathrm{d}$ was reported for transmissivity; 0.0002 for storage coefficient. Partly because of the locations of the observation wells and partly because of the nature of the fracture network, Hood (1976) considered the test to be atypical of the entire aquifer and the estimates of aquifer properties to be approximate at best. Hood (1976) reported 162 onsite estimates of hydraulic conductivity in the Duchesne River-Uinta aquifer in the northern Uinta Basin north of the Strawberry River. Seventy-five percent of these estimates was smaller than $4 \mathrm{ft} / \mathrm{d}$; their geometric mean was about $1.3 \mathrm{ft} / \mathrm{d}$.

The variogram of hydraulic conductivity with constant drift calculated from specific capacity tests (fig. 8) shows that large local variations in hydraulic conductivity exist within the Duchesne River-Uinta aquifer. The variogram corrected for drift is not shown but is virtually identical to the variogram in figure 8 . The average hydraulic-conductivity estimate given by the variogram is $23.2 \mathrm{ft} / \mathrm{d}$.

Several conflicting hypotheses can be inferred from the variogram of hydraulic conductivity. Three hypotheses that can be inferred are:

1. Effective basin hydraulic conductivity is uniform throughout the Duchesne River-Uinta aquifer. The value of hydraulic conductivity is similar to the average of estimates used in constructing the variogram $(23.2 \mathrm{ft} / \mathrm{d})$.

2. Local variations in hydraulic conductivity are so large that basin trends, though present, are masked. Under this hypothesis, point estimates are of limited use in identifying basin trends. Within the framework of fracture networks, such a hypothesis is possible when characteristics of a minor or local set of fractures are highly variable while characteristics of a set of major or basin fractures are more homogeneous. 


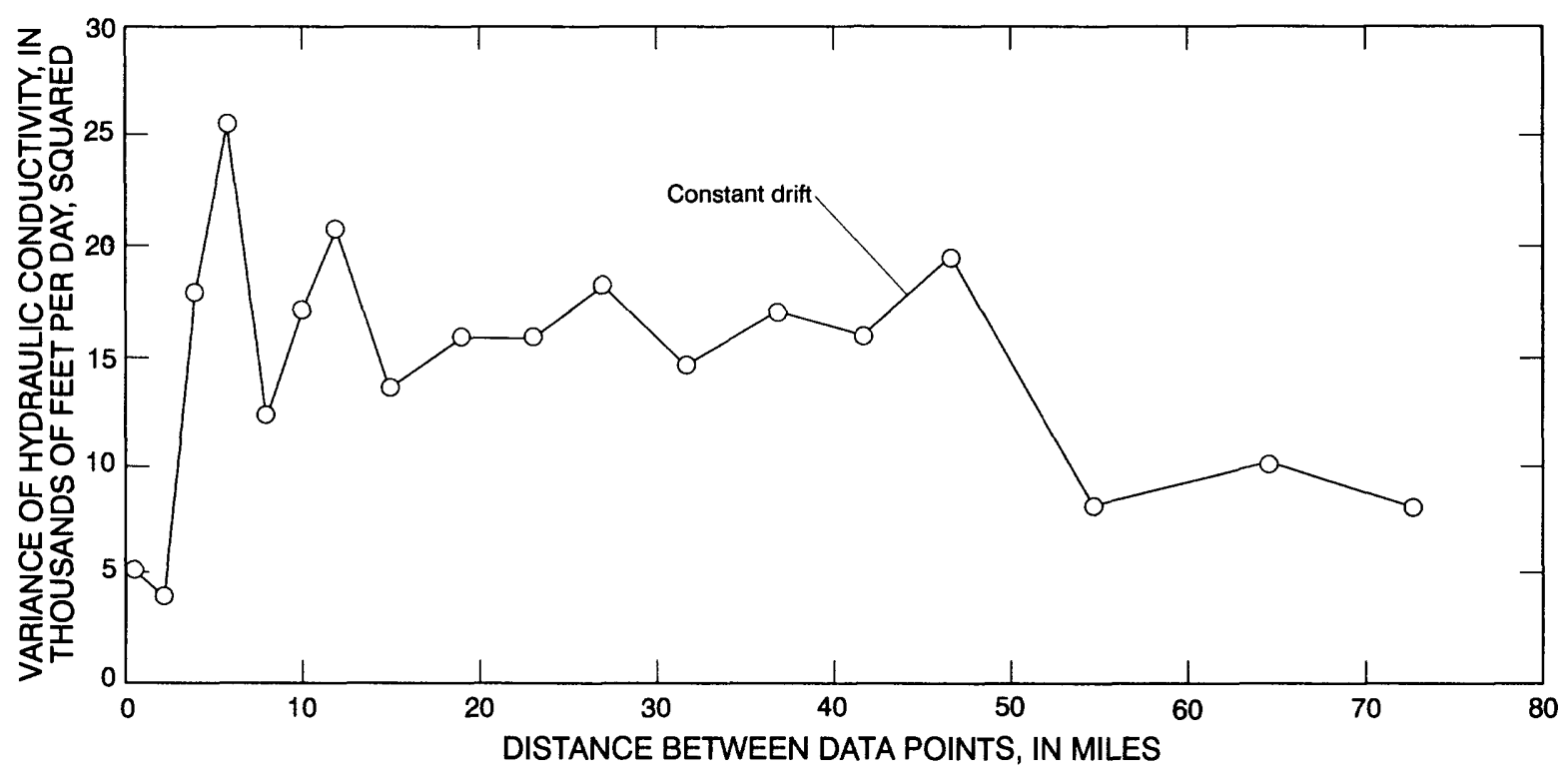

Figure 8. Variogram of hydraulic conductivity for the Duchesne River-Uinta aquifer.

3. Basin trends in hydraulic conductivity are significant. To a large degree, basin values of hydraulic conductivity are controlled by large fractures and tectonic features that either cannot be evaluated using local-scale measurements or are treated as boundary conditions in the interpretation of aquifer tests.

The digital model of ground-water flow described later in this report was used to evaluate the first hypothesis. The second hypothesis cannot be evaluated without detailed study of fracture networks in the Duchesne River-Uinta aquifer. The aquifer test and onsite estimates described by Hood (1976) are evidence that the third hypothesis may be realistic.

\section{ANALYSIS OF STEADY-STATE FLOW IN THE DUCHESNE RIVER-UINTA AQUIFER}

\section{Development of Flow Model}

Steady-state ground-water flow in the Duchesne River-Uinta aquifer was simulated with a mathematical model described by Cooley and Naff (1985) and modified by Garabedian (1984). The model was developed to check for consistency in estimates of ground-water recharge and discharge and estimated hydraulic-head distribution. In addition, the model was developed to estimate basin-scale aquifer transmissivity.
The model of the Duchesne River-Uinta aquifer is based on the differential equation of steady-state ground-water flow in two dimensions. The equation represents the physical processes present in the flow system. Because the differential equation cannot be solved directly, integrated finite-difference approximations were used, with nodes located at the corners of finite-difference blocks.

The nodal network established for the model, with uniform node spacing of $2.5 \mathrm{mi}$, encloses an area of about $4,190 \mathrm{mi}^{2}$ (fig. 9). The nodal spacing was selected in part on the basis of an analysis of hydraulichead variograms (fig. 6). These variograms indicate that variations in water-level measurements over distances of less than $5 \mathrm{mi}$ are the result of local variations in aquifer properties. Hence, a nodal spacing of $5 \mathrm{mi}$ is sufficient to evaluate basin variations in ground-water levels. However, a nodal spacing of $5 \mathrm{mi}$ is not sufficiently detailed to provide a good representation of boundary geometry. The nodal spacing of $2.5 \mathrm{mi}$ used in the model represents a practical compromise.

The lateral model boundaries are coincident, for the most part, with the boundaries of the Duchesne River and Uinta Formations (fig. 2) except along the southern edge of the Uinta Formation and in the area south of the White River. Along part of the southern boundary of the model, the Duchesne River and Uinta Formations are not present where they have been eroded by streams. Where erosion has occurred, the 


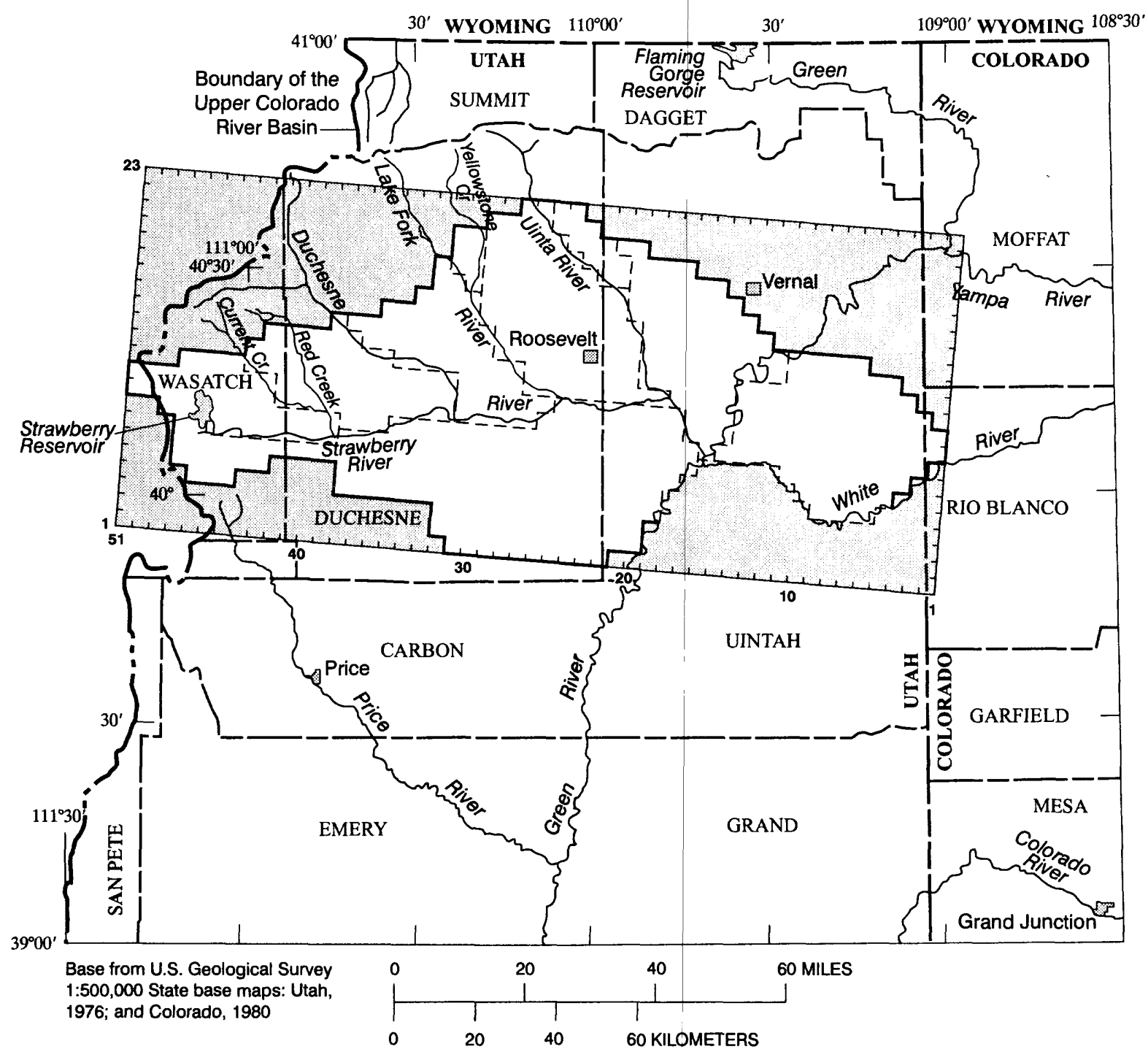

EXPLANATION

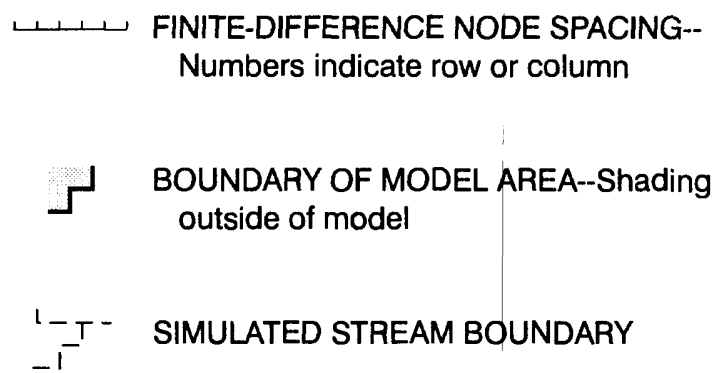

Figure 9. Finite-difference grid used to model ground-water flow in the Duchesne River-Uinta aquifer. 
underlying Green River Formation is exposed. Elsewhere along the southern boundary, the Uinta Formation is not saturated or, where saturated, basin movement of water does not occur. The boundaries all are represented as no-flow nodes; streams are represented by stream nodes. The area south of the White River was not included in the model after attempts to include the area produced unacceptable model results.

\section{Initial Estimates of Hydraulic Characteristics}

Information needed to begin developing a flow model of the Duchesne River-Uinta aquifer included the areal distribution and rates of aquifer recharge, the distribution and rates of aquifer discharge along streams, the distribution and magnitude of transmissivity, and the locations of measured water levels. Methods used to obtain these estimates were given in preceding sections; the initial estimates are reviewed briefly in this section and evaluated for reliability.

Recharge to the Duchesne River-Uinta aquifer, derived from precipitation and seepage from canals and streams, occurs primarily in upland areas along the margins of the Uinta Basin. Initial estimates (fig. 7) were obtained by a method that assumes recharge to be a percentage of average annual precipitation. The percentage is estimated by considering geology; physiography; and the volume, time, and areal distribution of precipitation. Although a quantitative evaluation of accuracy has not been undertaken, the method has been applied in many parts of Utah and has given useful results.

Discharge from the Duchesne River-Uinta aquifer, which occurs primarily along perennial streams, cannot be accurately measured. As a first approximation, gains or losses in average January streamflow for paired gaging stations on perennial streams were compared (table 1). Differences in streamflow at paired gaging stations are considered to be a first approximation because ungaged surface runoff was not considered and January stage measurements are affected by ice. Also, the rate of ground-water discharge generally is small compared to total stream discharge. January measurements are useful because the effects of evapotranspiration, bank storage surface runoff, and irrigation-return flow are generally at a minimum.

Transmissivity of the Duchesne River-Uinta aquifer is poorly defined. While thickness of the aquifer can be measured with reasonable accuracy, the analysis of hydraulic conductivity given previously shows that several interpretations are possible. Most of the apparent confusion can be related to a poor understanding of the fracture network of the Duchesne RiverUinta aquifer, and the fact that virtually all estimates of hydraulic conductivity are obtained from specificcapacity tests. However, estimates of hydraulic conductivity obtained from an aquifer test with observation wells cannot be considered to be very reliable due to a lack of knowledge about the fracture network.

Assuming an aquifer of nearly uniform thickness, transmissivity of the Duchesne River-Uinta aquifer was initially estimated to be $1,000 \mathrm{ft}^{2} / \mathrm{d}$. Variogram analysis of hydraulic conductivity for the Duchesne River-Uinta aquifer shows that a uniform value may be appropriate. Because of the simplistic approach taken for selecting an initial estimate, transmissivity was varied frequently during model development.

The location and values of measured water levels are accurately known. This accuracy however, must be evaluated in terms of generalized basin ground-water movement as opposed to smaller local flow systems that may vary from the generalized basin flow system. The variogram analysis of water-level measurements showed that differences in water levels on the order of $212 \mathrm{ft}$ could be expected at distances of $2.5 \mathrm{mi}$. Therefore, differences of $212 \mathrm{ft}$ could be attributed to local effects. For this reason a standard error of $212 \mathrm{ft}$ difference in water level was selected as one of the criteria for calibration of the hydrologic model.

\section{Calibration}

Simulation made using initial estimates of model parameters did not result in a hydrologically reasonable description of steady-state flow in the Duchesne RiverUinta aquifer. Specifically, hydraulic head at observation wells calculated during the initial steady-state simulation did not closely match field measurements.

Calculated aquifer head near streams that act as points of ground-water discharge generally were less than the altitude of the stream channel. Such a condition in a discharge area is physically unreasonable. This initial result was not unexpected, however, because initial estimates of transmissivity, and aquifer recharge and discharge were not based on reliable site data.

Because initial estimates of some model parameters were unreliable, the parameter values were varied until model-calculated head correctly simulated measured or known conditions. This process of varying model parameters to more accurately simulate reliable 
data is called calibration. Transmissivity was the principal model parameter varied during calibration. Estimates of aquifer recharge $\left(202 \mathrm{ft}^{3} / \mathrm{s}\right)$ were considered to be more reliable and were not changed substantially without data or sound hydrologic justification. Similarly, discharge estimates $\left(202 \mathrm{ft}^{3} / \mathrm{s}\right)$ were not changed substantially unless initial estimates were considered inaccurate. Streams along which recharge or discharge were considered inaccurate included the Green, White, and Uinta Rivers.

A statistical algorithm based on nonlinear regression techniques (Cooley, 1982) was used to calibrate the Duchesne River-Uinta aquifer model. The algorithm obtains estimates of model parameters that minimize the squared difference of calculated and measured head. Model parameters are treated within the algorithm as coefficients of a regression equation that, upon solution, is equivalent to the finite-difference equation of ground-water flow. Estimates of model parameters may be constrained within the algorithm if adequate information is available prior to the simulation. The constraint is included within the algorithm by providing both an initial estimate of the parameter value and a value for the error variance of the initial estimate. A boundary condition or aquifer property may be specified exactly by not including it as a parameter in the regression analysis. A computer program documented by Cooley and Naff (1985), and modified by Garabedian (1984) includes the statistical calibration algorithm.

Results of the statistical calibration algorithm include estimates of model parameters and a measure of model reliability, called the standard error, for each parameter. Each standard error has units equal to the units of the corresponding parameter. For example, the standard error of transmissivity has units of feet squared per day. Qualitatively, a small standard error, relative to the parameter estimate, indicates that the parameter is estimated with a good degree of accuracy. Also, a small standard error usually indicates the simulation results are relatively sensitive to changes in the parameter estimate.

Calibration of the Duchesne River-Uinta aquifer model was accomplished in a step-wise manner, beginning with relatively simple distributions of aquifer characteristics and boundary conditions, and proceeding to more complex distributions. In each step of the calibration process, values for model parameters were estimated by nonlinear regression and model-calculated hydraulic heads were compared with measured water-level data. If the standard error for the particular model run was greater than $212 \mathrm{ft}$, or if the comparison between calculated and measured heads was particularly poor in parts of the aquifer, a new distribution of model parameters was hypothesized and a nonlinear regression was repeated. This calibration approach is analogous to the forward-selection procedure for obtaining an appropriate regression equation (Draper and Smith, 1966, p. 169-171). The calibration criterion of $212 \mathrm{ft}$ was selected based on the analysis of the hydraulic-head variogram analysis discussed previously.

\section{Results of Flow Simulation}

The aquifer properties used in the ground-water flow model that resulted in the best simulation of basin geohydrologic conditions are described in this section of the report. A comparison of model results with measured geohydrologic data is presented in a later section.

\section{Recharge}

Ground-water recharge calculated in the final model calibration run indicated total recharge from precipitation was $262 \mathrm{ft}^{3} / \mathrm{s}$ and recharge from the Green River was about $8 \mathrm{ft}^{3} / \mathrm{s}$ (fig. 10). This varies from the initial estimates of recharge given in an earlier section of the report. Variations can be justified on the basis of physical characteristics not considered in the initial estimates. Recharge in the southern part of the model area is less than initially estimated by Price and Miller (1975). The difference in model calculated recharge and that initially estimated is not surprising because the initial estimate does not differentiate between local and basin ground-water flow when estimating recharge. Recharge in areas adjacent to the Uinta Mountains is greater than initially estimated by Hood and Fields (1978). The Duchesne River Formation along the Uinta Mountains is underlain by permeable aquifers of Mesozoic and Paleozoic age that may leak water upward into the Duchesne River-Uinta aquifer. Hood and Fields (1978) characterized ground-water movement in aquifers of Mesozoic and Paleozoic age by shallow circulation and short flow paths in areas adjacent to the Uinta Mountains. Smaller hydraulic conductivity in deeply buried parts of the Uinta Basin limits basin ground-water movement in aquifers of Mesozoic and Paleozoic age. 


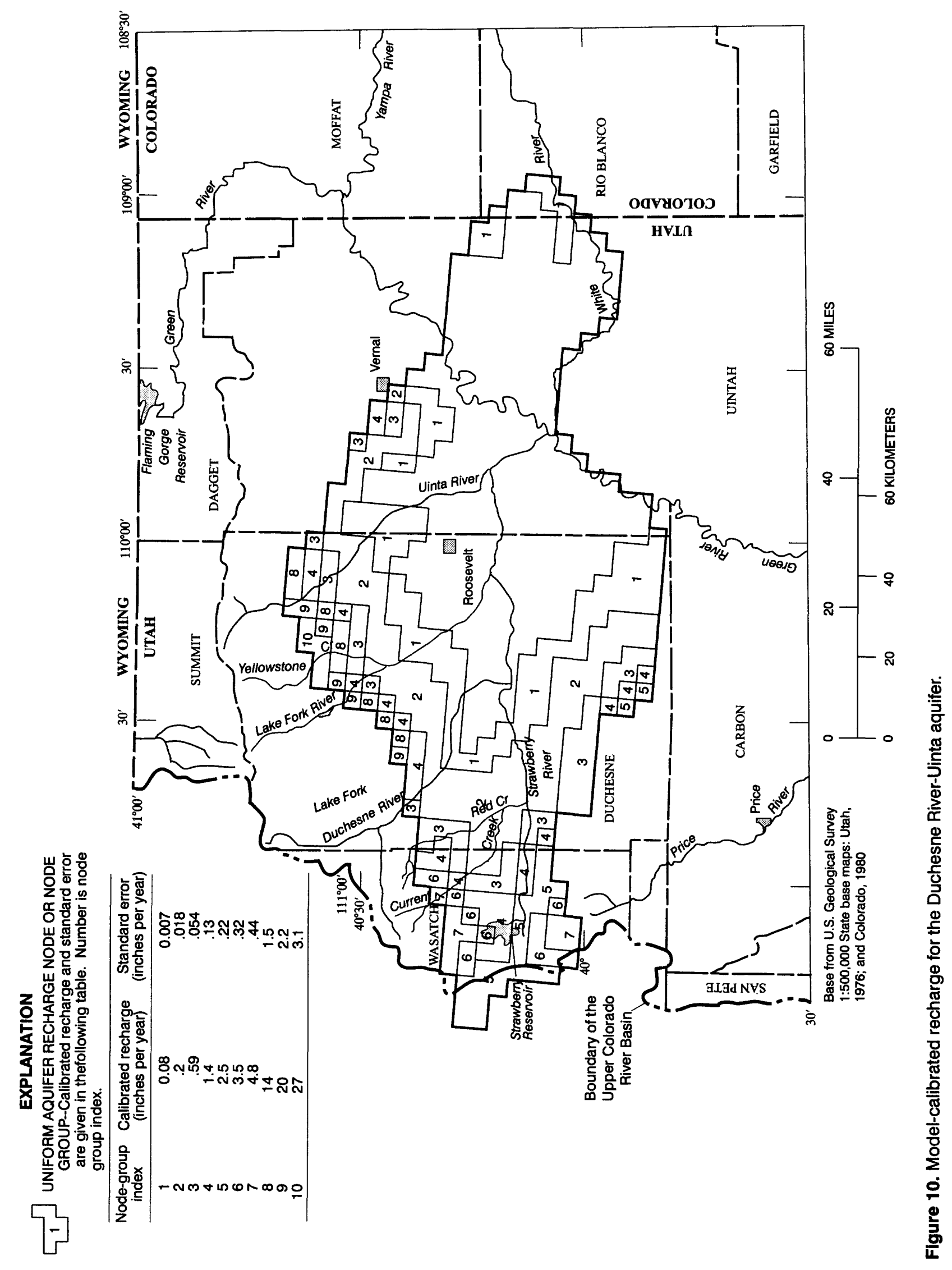




\section{Discharge}

Estimates of ground-water discharge to streams resulting from model calibration except for the Green and Uinta Rivers were not substantially different from initial estimates. The total discharge from the Duchesne River-Uinta aquifer to all streams after calibration of the model was about $270 \mathrm{ft}^{3} / \mathrm{s}$. Initial estimates of ground-water discharge to streams (table 1) obtained from an analysis of streamflow records were not believed to be accurate; however, varying most discharge estimates during model calibration did not improve the comparison between simulated and measured heads. This poor comparison is significant because errors in estimated aquifer discharge cause corresponding errors in other model parameters. This is because aquifer recharge, transmissivity, and other model parameters calculated during calibration are expressed in the model as a ratio to aquifer discharge.

Ground-water discharge to the Green and Uinta Rivers was estimated during model calibration. As discussed previously, initial estimates of discharge could not be made with confidence because any reasonable discharge was less than the accuracy of streamflow measurements. However, it was hypothesized that the Green River loses water to the Duchesne River-Uinta aquifer upstream from the mouth of the White River and the Green River gains water from the Duchesne River-Uinta aquifer downstream from the White River. This hypothesis was tested during model calibration and a net loss of about $8 \mathrm{ft}^{3} / \mathrm{s}$ from the Green River to the Duchesne River-Uinta aquifer was found to be reasonable. Similarly, a gain of about $45 \mathrm{ft}^{3} / \mathrm{s}$ to the Uinta River from the aquifer was found to be reasonable. Estimated ground-water recharge and discharge along the Green and Uinta Rivers are given in table 2. The standard errors of estimate are large, indicating the relation between the Green and Uinta Rivers and the Duchesne River-Uinta aquifer is very poorly understood.

\section{Transmissivity}

The basin distribution of transmissivity for the Duchesne River-Uinta aquifer obtained during model calibration, and the standard error of estimate are shown in figure 11. The values shown in the figure represent estimates of basin transmissivity and may sub
Table 2. Ground-water recharge and discharge along the Green and Uinta Rivers estimated during model development.

\begin{tabular}{lcc}
\hline & $\begin{array}{c}\text { Ground-water } \\
\text { recharge or } \\
\text { discharge (-) } \\
\text { (cubic feet } \\
\text { per second) }\end{array}$ & $\begin{array}{c}\text { Standard } \\
\text { error } \\
\text { (cubic feet } \\
\text { per second) }\end{array}$ \\
\hline Uinta River & -44.6 & 35.0 \\
$\begin{array}{c}\text { Green River-upstream } \\
\text { from White River }\end{array}$ & 9.4 & 31.3 \\
$\begin{array}{c}\text { Green River-downstream } \\
\text { from White River }\end{array}$ & -0.95 & 1.2 \\
\hline
\end{tabular}

stantially differ from estimates of transmissivity obtained from aquifer tests.

Large areas of the Duchesne River-Uinta aquifer are characterized by a transmissivity of about $4,400 \mathrm{ft}^{2} / \mathrm{d}$; however, the standard error of this estimate varies significantly. The central part of the model area, subarea 2 , is characterized by a large standard error of estimate--about $1,600 \mathrm{ft}^{2} / \mathrm{d}$. This may be a reflection of the greater density of water-level data and resulting better definition of local flow systems. Subarea 6, north of the White River is characterized by an even larger standard error of estimate--about $15,000 \mathrm{ft}^{2} / \mathrm{d}$. The small standard error in the southern part of the model area, subarea 1 , is about $450 \mathrm{ft}^{2} / \mathrm{d}$, possibly due to a scarcity of data.

Transmissivity within the Duchesne fault zone (subarea 3) probably is less than within adjacent areas. However, this conclusion is tentative because the standard error of estimate for this subarea is nearly as large as the transmissivity value. The hypotheses of anisotropy and large transmissivity within the Duchesne fault zone were tested during model calibration but did not improve the model. The model insensitivity may be due to a lack of water-level data within the fault zone.

Transmissivity in the western part of the model area, subarea 5 , is less than in the southern part, subarea 1, and central part, subarea 2. Faults are common in the western part of the model area, as are local flow systems. The smaller basin transmissivity may be a reflection of the large component of local flow. Transmissivity at a local scale may be significantly different from transmissivity at a basin scale. Faults may act as boundary conditions for local flow systems and 


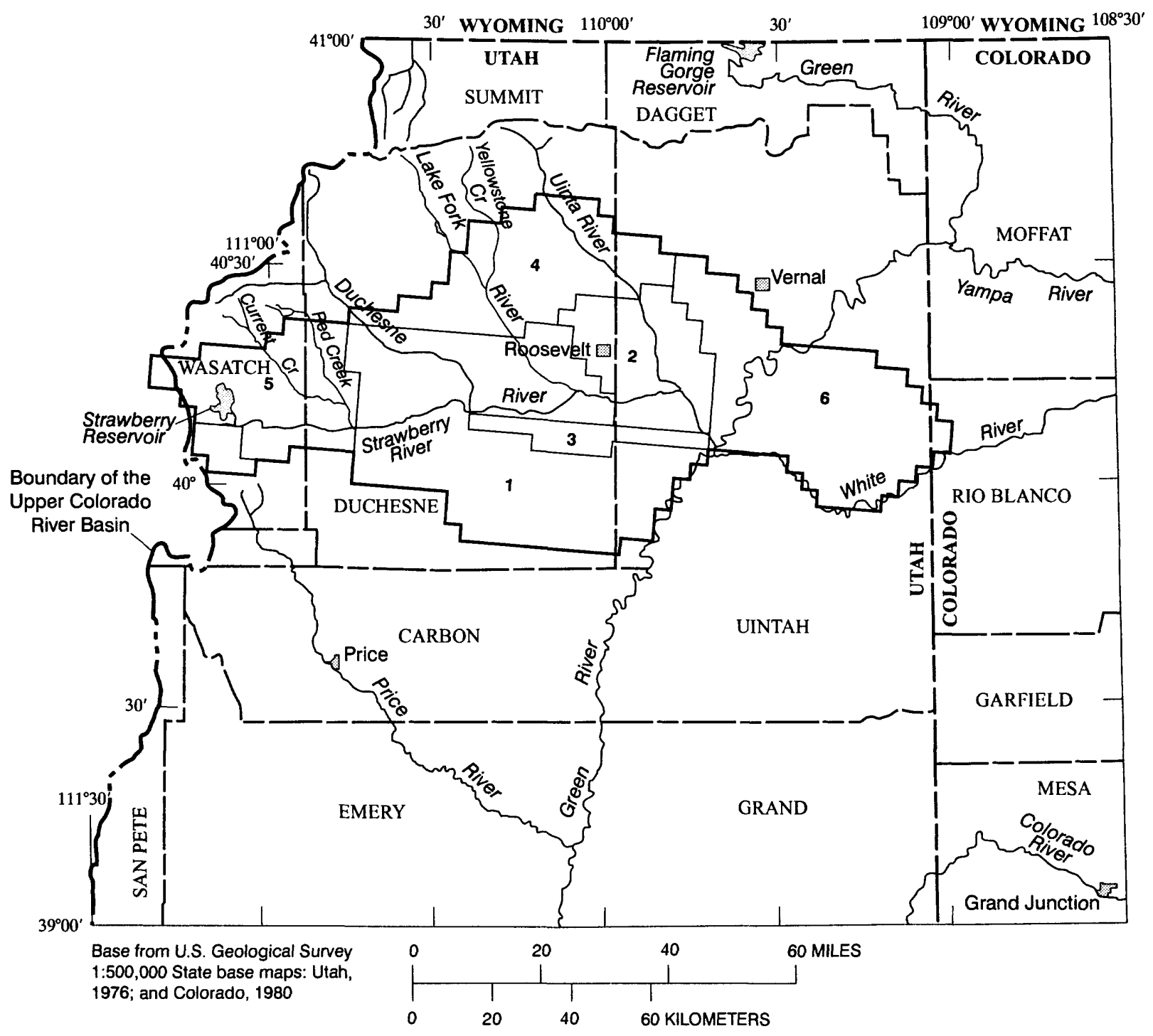

EXPLANATION

AQUIFER SUBAREA--Simulated uniform transmissivity values and associated standard errors of estimate given in the following table. Number is subarea designation.

\begin{tabular}{ccc}
\hline $\begin{array}{c}\text { Aquifer } \\
\text { subarea }\end{array}$ & $\begin{array}{c}\text { Transmissivity } \\
\text { (feet squared per day) }\end{array}$ & $\begin{array}{c}\text { Standard error } \\
\text { (feet squared per day) }\end{array}$ \\
\hline 1 & 4,400 & 450 \\
2 & 4,400 & 1,600 \\
3 & 610 & 440 \\
4 & 2,200 & 240 \\
5 & 2,400 & 480 \\
6 & 4,500 & 15,000 \\
\hline
\end{tabular}

Figure 11. Basin distribution of transmissivity for the Duchesne River-Uinta aquifer. 
restrict basin movement of water. This restriction would effectively reduce basin transmissivity.

Transmissivity also is less along the Uinta Mountains resulting in relatively steep hydraulic gradients compared to the central part of the basin. The Uinta Formation is absent in this area, and the Duchesne River-Uinta aquifer may be thinner than in areas farther south. The standard error of estimated transmissivity also is small, possibly due to data scarcity.

\section{Comparison of Simulation Results with Measured Water-Level Data}

One method for evaluating results of the simulations is to compare calculated hydraulic head with measured water-level data. Model-calculated hydraulic head in the Duchesne River-Uinta aquifer compares favorably with measured water-level data based on a large value of the coefficient of determination, 0.97 . This means that 97 percent of the variance in the measured heads was simulated.

The standard error of calculated head, a measure of overall model fit, is $187 \mathrm{ft}$. The standard deviation of measured water levels separated by a distance equal to the model-node spacing (fig. 6) is $212 \mathrm{ft}$. By this criterion the model of the Duchesne River-Uinta aquifer is considered to be reasonable. Contours of the simulated hydraulic head are shown on figure 12 .

Residuals, the difference between calculated and measured water levels, also were analyzed to evaluate the adequacy of the flow model. A.model adequately describes ground-water flow if the distribution of residuals is approximately random with a mean of zero. If the residuals show definite areal patterns then additional calibration may be needed. Graphical procedures described by Draper and Smith (1966, p. 86-99) and visual analysis of the results were used. Visual analysis is an adequate method for detecting trends in residuals because the Duchesne River-Uinta aquifer model is not intended to be used as a predictive tool.

A graph of residuals plotted as a function of model-calculated hydraulic head showed the distribution of residuals to be approximately random. The variance of residuals did not appear to increase or decrease as a function of calculated head. Residuals also appeared to be distributed with a mean of approximately zero. When calculated, the mean residual was $8 \mathrm{ft}$. This is not significantly different from zero.
A map plot of residuals and wells, where waterlevel measurements were available (fig. 13), indicated that simulated hydraulic head along Lake Fork River is consistently underestimated. This error in calculated heads has resulted in compensating positive residuals both east and west of Lake Fork River. The discrepancy may be due to unmapped and unmodeled glacial outwash deposits that provide locally important recharge water to Lake Fork River and form a local flow system. Areally distributed recharge along Lake Fork River was not included in the model of the Duchesne River-Uinta aquifer because the hypothesized recharge only represents a local condition.

In all other areas of the model of the Duchesne River-Uinta aquifer, the map plot of residuals showed that basin variations in transmissivity, recharge, and discharge are adequately described. Although figures 6 and 8 show that significant local deviations from basin trends are common, basin variations can be described by relatively few model parameters. As figure 11 shows, only six values of transmissivity were needed to calibrate the model. Future investigations directed toward reducing the magnitude of residuals will need to emphasize the role of local flow systems in the Duchesne River-Uinta aquifer. 


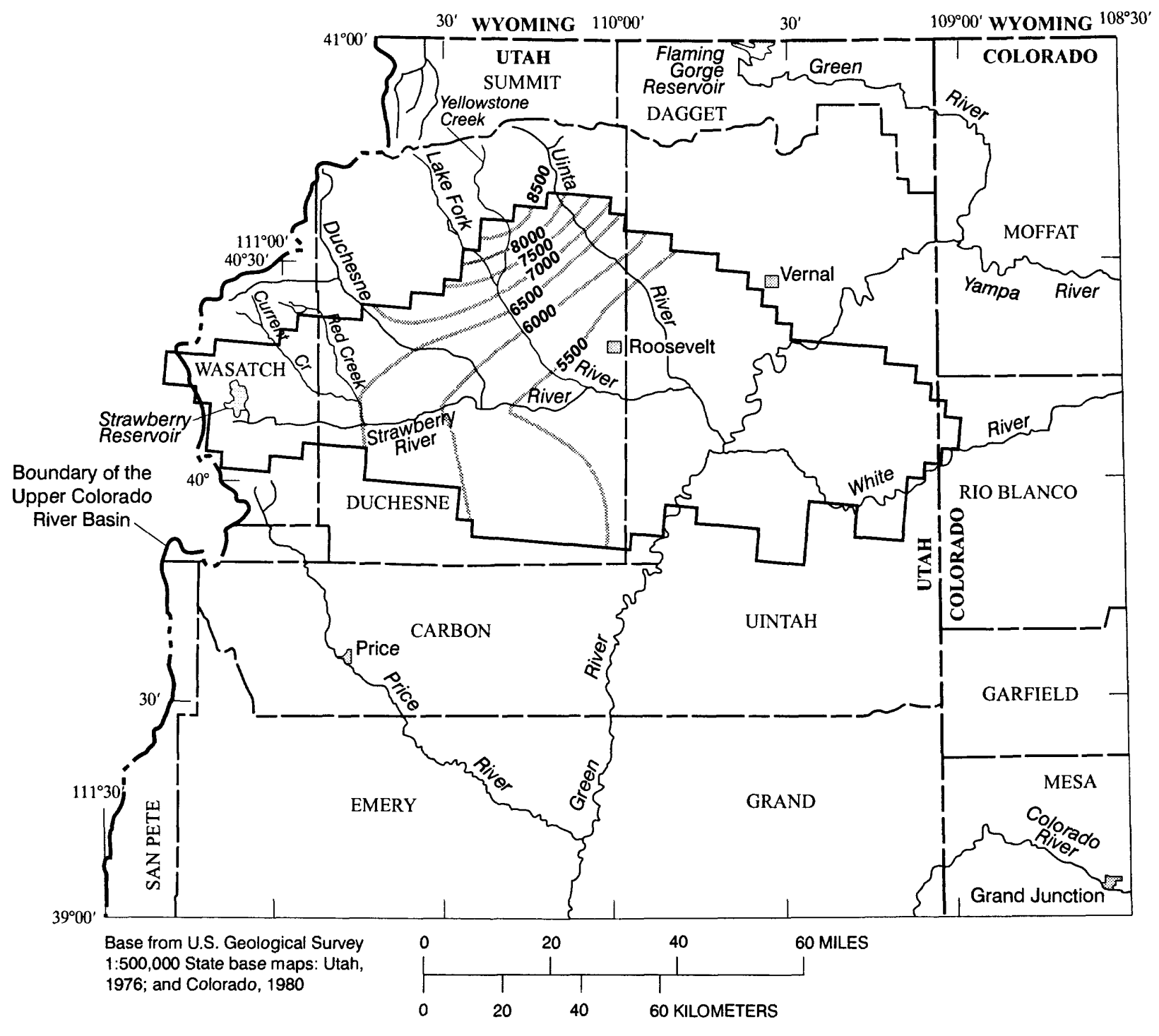

EXPLANATION

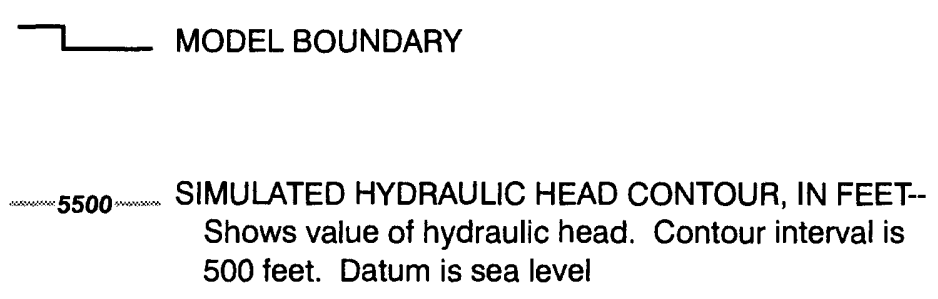

Figure 12. Simulated hydraulic-head contours for the Duchesne River-Uinta aquifer. 


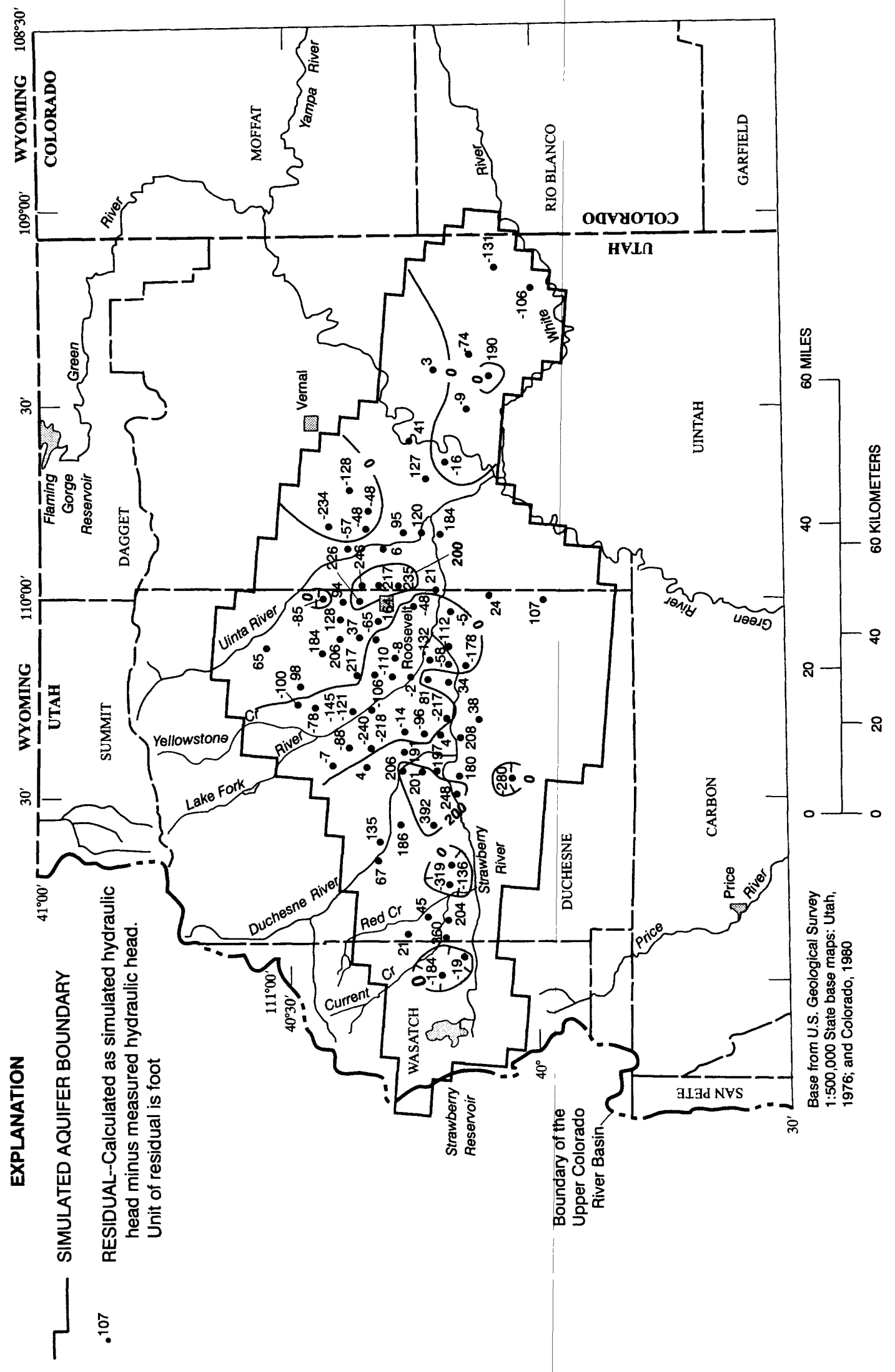

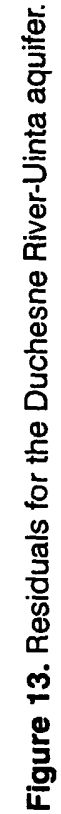




\section{SUMMARY}

The Duchesne River-Uinta aquifer, comprised of the Duchesne River and Uinta Formations, is an important basin aquifer in the Uinta Basin of Utah and Colorado. The aquifer consists of about $8,000 \mathrm{ft}$ of variegated red shale, thinly bedded calcareous shale, siltstone, sandstone, and conglomerate. The Parachute Creek Member of the Green River Formation forms a relatively impermeable bottom for the Duchesne River-Uinta aquifer.

Ground water in the Duchesne River-Uinta aquifer is present within a complex system of shallow water-table, perched, and deep artesian conditions. Ground-water recharge is derived from precipitation and from seepage losses from canals and streams. Ground-water discharge is from the Duchesne RiverUinta aquifer into the thin alluvial deposits along the major streams and ultimately into the stream channels.

The potentiometric surface of the Duchesne River-Uinta aquifer indicates basin variations in hydraulic head and can be used to infer directions of basin ground-water movement. Analysis of variograms indicates that the difference in hydraulic head expressed by measurement of data points less than $5 \mathrm{mi}$ apart is caused by local hydrologic effects. The difference in hydraulic head expressed by measurement of data points separated by 5 to $40 \mathrm{mi}$ is caused by both local and basin effects. The difference in hydraulic head expressed by measurement of data points greater than $40 \mathrm{mi}$ apart is caused by basin effects.

A computer model was developed to simulate steady-state ground-water flow in the Duchesne RiverUinta aquifer. Calibration of the model was done in a step-wise manner, beginning with relatively simple distributions of aquifer characteristics and boundary conditions, and proceeding to more complex distributions when simple models proved inadequate. Distributions of aquifer characteristics and boundary conditions tested during model calibration were supported by geologic or hydrologic evidence.

The model of the Duchesne River-Uinta aquifer was used to refine estimates of ground-water recharge. Recharge to the basin ground-water system in the southern part of the model area is less than previously calculated, while recharge in areas adjacent to the Uinta Mountains is greater. With the exception of the Green and Uinta Rivers, estimates of ground-water discharge to streams used during model calibration were not significantly different from initial estimates.
The distribution of basin transmissivity for the Duchesne River-Uinta aquifer was obtained during model calibration. Large areas of the Duchesne RiverUinta aquifer are characterized by a transmissivity of about $4,400 \mathrm{ft}^{2} / \mathrm{d}$. Transmissivity within the Duchesne fault zone and in the western part of the study area probably is smaller than in adjacent areas. Along the Uinta Mountains, smaller transmissivity has resulted in relatively steep hydraulic gradients.

Model-calculated hydraulic head compares favorably with measured water-level data. A map of the difference of calculated and measured water levels shows that basin variations in transmissivity, recharge, and discharge are adequately described. Future investigations will need to emphasize the role of local flow systems in the Duchesne River-Uinta aquifer.

\section{SELECTED REFERENCES}

Andersen, D.W., and Picard, M.D., 1972, Stratigraphy of the Duchesne River Formation (Eocene-Oligocene?), northern Uinta Basin, northeastern Utah: Utah Geological and Mineralogical Survey Bulletin 97, 29 p.

Cooley, R.L., 1982, Incorporation of prior information on parameters into nonlinear regression groundwater flow models, 1, Theory: Water Resources Research, v. 18, no. 4, p. 965-976.

Cooley, R.L., and Naff, R.L., 1985, Regression modeling of ground-water flow: U.S. Geological Survey Open-File Report 85-180, 450 p.

Dane, C.H., 1954, Stratigraphic and facies relationships of upper part of Green River Formation and lower part of Uinta Formation in Duchesne, Uintah, Wasatch Counties, Utah: American Association of Petroleum Geologists, v. 38, no. 2, p. 405-425.

Draper, N.R., and Smith, H., 1966, Applied regression analysis: New York, John Wiley, 407 p.

Fields, F.K., and Adams, D.B., 1975, Temperature and precipitation estimates for northeastern Utah: U.S. Geological Survey Journal of Research, v. 3, no. 2, p. 131-136.

Garabedian, S.P., 1984, Application of a parameterestimation technique to modeling the regional aquifer underlying the eastern Snake River plain, Idaho: U.S. Geological Survey Open-File Report 84-461, 119 p.

Hintze, L.F., 1980, Geologic map of Utah: Utah Geological and Mineral Survey, scale 1:500,000, 2 sheets.

1988, Geologic history of Utah: Provo, Utah, Brigham Young University Geology Studies, Special Publication 7, $204 \mathrm{p}$. 
Holmes, W.F., and Kimball, B.A., 1983, Ground water in the southeastern Uinta Basin, Utah and Colorado: U.S. Geological Survey Open-File Report 83-271, 164 p.

Hood, J.W., 1976, Characteristics of aquifers in the northern Uinta Basin area, Utah and Colorado: Utah Department of Natural Resources Technical Publication 53, $71 \mathrm{p}$.

Hood, J.W., and Fields, F.K., 1978, Water resources of the northern Uinta Basin area, Utah and Colorado, with special emphasis on ground-water supply: Utah Department of Natural Resources Technical Publication 62, $75 \mathrm{p}$.

Journel, A.G., and Huijbregts, Ch.J., 1978, Mining geostatistics: New York, Academic Press, 600 p.

Long, J.C.S., Remer, J.S., Wilson, C.R., and Witherspoon, P.A., 1982, Porous media equivalents for networks of discontinuous fractures: Water Resources Research, v. 18 , no. 3 , p. 645-658.

Kimball, B.A., 1981, Geochemistry of spring water, southeastern Uinta Basin, Utah and Colorado: U.S. Geological Survey Water-Supply Paper 2074, 30 p.

Price, D., and Miller, L.L., 1975, Hydrologic reconnaissance of the southern Uinta Basin, Utah and Colorado: Utah Department of Natural Resources Technical Publication 49, 66 p.

Skrivan, J.A., and Karlinger, M.R., 1980, Semi-variogram estimation and universal kriging program: U.S. Geological Survey Computer Contribution, 98 p.

Taylor, O.J., Hood, J.W., and Zimmerman, E.A., 1983, Plan of study for the regional aquifer systems analysis of the Upper Colorado River Basin in Colorado, Utah, Wyoming, and Arizona: U.S. Geological Survey Water-Resources Investigations Report 83-4184, 23 p.

Toth, J., 1963, A theoretical analysis of groundwater flow in small drainage basins: Journal of Geophysical Research, v. 68, p. 4795-4812. 